\title{
Örgütsel Travmalar: Beyaz Yakalı Çalışanlarda Algılanan Travma Riski ve Örgütsel Dayanıklılık ile İlişskisi
}

\author{
Esin ÇETIN ÖZBUDAK ${ }^{1}$, İdil IŞIK²
}

\begin{abstract}
Özet: Nitel ve nicel fazları barındıran karma bir tasarıma sahip olan bu araştırma, örgütsel travma kavramından hareket ederek, ülkemizde çalışanların iş yaşamında hangi olayları travmatik deneyim olarak algıladıklarını incelemektedir. Odak grup çalışmasında, şirketlerde gündelik akışı bozabilen, çalışanları olumsuz duygu durumuna sokabilen 36 olay türü tespit edilerek, ikinci fazda kullanılacak "Örgütsel Travmatik Olaylar Ölçeği” hazırlanmıştır. Bu ölçeğin, Örgütsel Dayanıklılık Ölçeği ile birlikte 145 beyaz yakalı profesyonele uygulanmasıyla ilerleyen araştırma, Çok Boyutlu Ölçeklendirme Analizinde ortaya çıktı̆̆ üzere potansiyel travmatik etki yaratabilecek olayların, bireysel ve örgütsel düzeyde etkiye sahip olaylar olarak iki eksende gruplandığını ve örgütsel düzey eksenine dair algılanan riskin, bireysel düzeye göre daha yüksek olduğunu göstermiştir. Yöneticilerin, yönetici olmayanlara göre algıladıkları riskin her iki düzey için daha düşük olduğu da görülmüş̧ür. Ayrıca, travmatik olay risk algısıyla örgütsel dayanıklılık algısı arasında istatistiksel olarak anlamlı negatif ilişki tespit edilmiş̧ir.
\end{abstract}

Anahtar Kelimeler: Örgütsel travma, önlenebilme, maruz kalma olasıllı̆ı, travmatik olaylar, örgütsel dayanıklılık.

\section{Organizational Trauma: Perceived Risk for Trauma among White-Collar Professionals and Its Relationship with Organizational Resilience}

\begin{abstract}
This research, with mixed design, examines which events in our country are perceived as a traumatic experience by white-collar employees, acting from the concept of organizational trauma. In the focus group study, 36 types of events that could disrupt the daily flow in companies and put employees in a negative mood were identified, and "Organizational Traumatic Events Scale" was developed. This scale was applied to 145 white-collar professionals, along with the Organizational Resilience Scale. As a result of Multidimensional Scaling Analysis, the events that may have a potential traumatic effect were grouped on two axes as events with an individual and organizational level effect. The results showed that the perceived risk of organizational level axis events is higher than the individual level axis events and that the risks perceived by managers compared to non-managers was lower for both axes. Besides, a statistically significant negative relationship was found between the perception of organizational resilience and the perceived risk of traumatic events.
\end{abstract}

Keywords: Organizational trauma, preventability, exposure, traumatic events, organizational resilience.

${ }^{1}$ Uzm. Psk., İstanbul Bilgi Üniversitesi, Psikoloji Bölümü, İstanbul, Orcid Id: https://orcid.org/ 0000-0003-3730-2718

${ }^{2}$ Doç. Dr., ., İstanbul Bilgi Üniversitesi, Psikoloji Bölümü, İstanbul, Orcid Id: https://orcid.org/ 0000-0002-6709-9717

Address of correspondence/ Yazışma adresi: Doç. Dr. İdil Işık, İstanbul Bilgi Üniversitesi, Örgütsel Psikoloji Yüksek Lisans Program1,E-mail: idil.isik@ bilgi.edu.tr

Date of received/ Geliş Tarihi: 01.03.2020, Date of Revision/ Düzeltme Tarihi: 17.04.2020, Date of acceptance/ Kabul Tarihi: 04.05.2020

Citing/ Referans Gösterimi: Çetin Özbudak, E., Işık, İ. (2020). Örgütsel Travmalar: Beyaz Yakalı Çalışanlarda Algılanan Travma

Riski ve Örgütsel Dayanıklılık ile İlişkisi. Kıbrıs Türk Psikiyatri ve Psikoloji Dergisi, 2 (2): 97-105 doi:10.35365/ctjpp.20.02.14 


\section{Giriş}

Marmara depremi (17 Ağustos 1999), Karabük’teki demirçelik fabrikalarının üretime ara vermesi sonucu 1500 kişinin işsiz kalması (Aralık 2008), futbol kulüplerine yönelik şike davası (2011), Soma maden faciası (13 Mayıs 2014), Bursa'da metal sektörü işçi direnişleri (2015), Atatürk Havalimanı terör saldırısı (29 Haz 2016), Eskişehir'de bir araştırma görevlisinin, dört akademisyen ve idari personeli silahlı saldırı sonucunda öldürmesi (5 Nisan 2018), ülkemizde politik ve ekonomik sorunlar neticesinde Türk Lirasının değer kaybetmesine bağlı finansal krizler (2018) ve en güncel deneyim olarak, ülkemizi ve tüm dünyayı etkisi altında bırakan Koronavirüs (Covid-19) pandemisi... Bu olaylar toplum hafızasına kazınmış olmanın yanında, çalışanları bireysel düzeyde, kurumları kolektif ölçekte etkileyen deneyimlerdir ve doğrudan maruz kalan ya da tanıklık etmiş kişilerin gündelik yaşamını sarsarak, başa çıkabileceklerinden fazla stres yaratır, kısa, orta ve uzun vadede etkilerini sürdürürler (Hopper, 2010; Pena, Broucke, Sylin, Leysen ve Soir, 2017; Venugopal, 2016). Organizasyonların ve çalışanların maruz kaldığı, iç ve dış kaynaklı bu yıpratıcı olaylar ve içine düştükleri bağlam, literatürde "örgütsel travma" başlığıyla incelenmektedir (Işık, 2017). Doğal afetler, savaş koşulları, ekonomik kriz ve terör saldırıları, bir kurumun istikrarını ve güvenliğini zayıflatacak dış kaynaklı olaylara örnek verilebilir (Annarelli ve Nonino, 2016; Burke, 2012). Örgüt içindeki ayrımcılık, sabotaj, psikolojik yıldırma gibi verimlilik karşıtı davranışlar da hem maruz kalanlar hem de tanıklık edenler için psikolojik olarak yıpratıcidır (Hormann ve Vivian, 2005). Organizasyonel yeniden yapılanma (Stuart, 1996), küçülme nedeniyle işten çıkarmalar (Noer, 1993), şirket içi birleşmeden kaynaklanan belirsizlikler de örgütsel travmaya neden olabilir (Denenberg ve Denenberg, 2010). Doğru müdahale edilmezse, kolektif travma deneyimi, çalışanların işlevsiz davranışlarına yol açar (De Klerk, 2007; Steinkamp, 2014), problem çözme ve görevlere odaklanma becerisinde eksiklik, anksiyete, depresyon, öfke gibi duygusal sorunlar doğurabilir (Buckley ve Dunn, 2012; Kahn, 2003); örgütten ayrılma niyetini tetikler (Gabriel, 2012).

Literatürde örgütsel travmaya neden olabilecek olayların, çoğunlukla tekil olaylardan hareketle vaka çalışmaları ve teorik taramalarla incelendiğini ve sistematik bir tanımlaması olmadığını görüyoruz. Iş̧1k (2017a) bu ihtiyaçtan hareketle yürüttüğü sistematik literatür taramasında, potansiyel travmatik olayları üç kategoride tanımlar: (a)örgütsel süreçlerden kaynaklanan travmatik olaylar; (b)travmaya meyilli örgütler/meslekler/sektörlerin maruz kaldığı olaylar; (c)ekonomik/sosyal/çevresel koşullara bağlı travmatik olaylar. Birincisinde, örgütsel/insan yapımı hatalar, kilit üyelerin ölümü, çalışan sağlığı, güvenliği sorunları, örgütsel değişim ve kötü muameleler yer alır. Travmaya meyilli örgütler/meslekler/sektörler kategorisi; tehlikeli maddelerle çalışan, acil durumlara ve bunları yaşayanlara müdahale eden kuruluşları ve mesleklerin deneyimlediği olayları kapsamaktadır. Ekonomik/sosyal/çevresel koşullarla ilgili olaylar; afetler, soygun, terör, savaş, finansal ve sağlık krizi gibi olaylardır.

\section{Örgütsel Dayanıklılık}

Alanyazında örgütsel dayanıklılık, bir olay ya da krizden sonra eski duruma geri dönme, toparlanma, iyileşme, durumdan en az hasar alarak başa çıkma ve değişme kapasitesi (De Galizia, Simon, Weber, Iung, Ducal, \& Serdet, 2016; Holling, 1973; Hormann, 2007; Limnios, Mazzarol, Ghadouani, \& Schilizzi, 2014; Powley, 2012; Somers, 2009); şoka direnme ve tepki verme yeteneği (Annarelli ve Nonino, 2016); ve olumsuz, travmatik deneyimler yaşanırken işlevsel şekilde hareket etme, düzgün çalışmayan unsurları tanıyarak beklenmedik durumlarla başa çıkma kapasitesi olarak tanımlanmaktadır (King, Newman ve Luthans, 2016; Mandojana \& Bansal, 2015).

Travmatik olaylarla karşılaştı̆̆ında sağlam durabilen ve duramayan örgütler arasındaki farkta dayanıklılığın güçlü bir etkisi vardır. Travmatik bir olay, bazı örgütlerin işleyişini bozabilir, sağlıklı aksiyon almasını etkileyebilir; hatta organizasyonun ölümüne neden olabilir. Oysa, bazı kuruluşlar aynı deneyimden öğrenebilir, dayanıklılık kazanabilir ve esnekliğini artırabilir. Kantur ve İşeri (2015) dayanıklı organizasyonların özellikleri arasında finansal güç, alternatif planlar geliştirme, risklere karşı hazırlıklı olma ve bir bütün olarak hılı hareket etme yeteneğini tanımlamaktadır.

Literatürde, örgütsel travma konusunu çalışanların perspektifinden, doğrudan ve/veya dolaylı olarak araştıran akademik çalışma bulunmamaktadır. $\mathrm{Bu}$ sebeple, araştırmamız, keşifsel bir yaklaşımla, algılanan örgütsel travma riskini sistematik şekilde ölçmeyi hedeflemektedir. Çalışanların hangi olası travmatik olaylar için organizasyonlarını daha fazla risk altında algıladıkları; bu travmatik olaylara ilişkin risk algısının, örgütsel dayanıklılık algısıyla ilişkisi ve yönetim rolünün örgütsel travma açısından risk algısında fark yaratıp yaratmadığ araştırmada cevap aranan sorularıdır.

\section{Gereç ve Yöntem}

İstanbul Bilgi Üniversitesi'nden Etik Komite onayına sahip bu çalışma, 2017-2018 yılları arasında verisi toplanan, nitel ve nicel araştırma tekniklerini kullanan karma yöntem tasarımına sahiptir.

\section{Nitel Araştırma Fazı}

Araştırmanın nitel fazı için bir tekstil şirketinin lojistik merkezinden 10'u kadın, 11'i erkek 21 çalışanın (yaş ort. $=31,00, \quad \mathrm{SS}=6,50)$ gönüllü katılımıla ortalama 30 dakikalık odak grup toplantıları gerçekleştirilmiştir (Tablo 1). Bu fazda, katılımcılara öncelikle örgütsel travma kavramını açıklayarak sözlü tartışma için sorular yöneltilmiştir; ses kaydı alınamadığı için hazırlanan formlara kurum içinden ve dışından hangi olayların örgütlerinde travmatik etki yaratabileceğini yazmaları istenmiştir. Ardından, içsel ya da dışsal neden ayrımına gitmeksizin, örgütsel travmaya neden olabileceğini düşündükleri en riskli üç olayı belirtmelerini istenmiştir. 
Tablo 1. Odak grup katılımcılarının betimleyici istatistikleri

\begin{tabular}{|c|c|c|c|c|}
\hline Katılımcıların Ünvanı & Cinsiyet & $n$ & Yaş Ort. & $S$ \\
\hline Çalışan İlişkileri Müdürü & Erkek & 1 & 38,00 & - \\
\hline Çalışan İlişkileri Temsilcisi & Erkek & 4 & 31,25 & 4,57 \\
\hline Çalışan İlişskileri Uzmanı & Kadın & 1 & 29,00 & - \\
\hline Çalışan İlişkileri Depertman Asistanı & Erkek & 1 & 38,00 & - \\
\hline İnsan Kaynakları Departman Asistanı & Erkek & 1 & 24,00 & - \\
\hline \multirow[t]{2}{*}{ İnsan Kaynakları Uzman Yardımcısı } & Kadın & 4 & \multirow[t]{2}{*}{24,60} & \multirow[t]{2}{*}{0,54} \\
\hline & Erkek & 1 & & \\
\hline İnsan Kaynakları Uzmanı & Kadın & 3 & 29,66 & 2,51 \\
\hline Satınalma Uzman Yardımcısı & Erkek & 1 & 41,00 & - \\
\hline Kalite Kontrol ve Denetim Uzmanı & Kadın & 1 & 50,00 & - \\
\hline Sosyal Sorumluluk ve Destek Uzmanı & Erkek & 1 & 31,00 & - \\
\hline \multirow[t]{2}{*}{ İş Sağlığı ve Güvenliği Uzmanı } & Kadın & 1 & \multirow[t]{2}{*}{32,00} & \multirow[t]{2}{*}{-} \\
\hline & Erkek & 1 & & \\
\hline
\end{tabular}

Odak grup veri toplama formlarındaki cevapları MAXQDA nitel veri analizi yazılımına aktarılmıştır. Potansiyel travmatik olaylarla ilgili kavramların sıklıkları otomatik sayma yöntemiyle kontrol edildiğinde, Tablo 2'de görülen, beş kez ve daha fazla tekrara sahip olan kavramlarla karşılaşılmıştır.

Tablo 2. Odak gruplarda geçen, travma ile ilgili kelimelerin tekrarlanma sıklığ1

\begin{tabular}{llll}
\hline Kelime & Sıklık Sılık & Kelime & 6 \\
\hline Terör & 16 & Ekonomik & 6 \\
Saldırı & 15 & Yangın & 6 \\
CEO & 9 & Çarpışma & 6 \\
Afet & 8 & Zehirlenme & 6 \\
Ölüm & 7 & Ayrımcılık & 5 \\
Kriz & 7 & Çatışma & 5 \\
Kaza & 7 & Kayıp & 5 \\
Kavga & 6 & Patlama & 5 \\
Uyuşturucu & 6 & Salgın & 5 \\
Cinsel & 6 & Deprem & \\
Kötüye kullanma & 6 & & 5 \\
\hline
\end{tabular}

Cevapları tümevarıma dayalı nitel veri analizi yaklaşımıyla sistematik şekilde kodladığımızda ise açık kodlama aşamasında, 203 alt temaya ulaştık; en sık rastlanan kod "ölümlere/sakatlanmalara neden olan iş kazaları" oldu (frekans $=25$ ). Terör saldırıları, deprem ve diğer doğal afetler (frekans=13), ayrımcılık ve eşitsizlik (frekans=12), gruplar arası çatışma (frekans=11) sık görülen diğer kodlardır. Bunlar, 36 travmatik olay altında gruplanabildi ve Örgütsel Travmatik Olaylar Ölçeği adı verilen ölçeğin maddelerini oluşturdu. $\mathrm{Bu}$ aşamada, amacımız farklı kuruluşlar ve sektörler için geçerli olabilecek bir araç geliştirmek olduğundan, en düşük frekanslara sahip kodlar da anket maddelerine dönüştürüldü.

\section{Nicel Araştırma Fazı}

Nicel aşamaya, kolayda örnekleme yoluyla farklı şirketlerden beyaz yakalı çalışanlar $(\mathrm{N}=145)$ katıldı (yaş ortalaması $=34,5$, min. $=22$, maks. $=70, \mathrm{SS}=7,6, \% 47,5$ kadın; $\% 46,8$ yönetici). Katılımcıların \%66,2'si beş yıl veya daha kısa süredir mevcut organizasyonunda; \%91,7'si özel sektörde; \%62'si büyük ölçekli kuruluşlarda çalışmaktadır. Örneklemin çoğunluğu hizmet sektöründendir ( $\% 59,3$; üretim $=\% 40,7)$.

Bu aşamada, bir önceki fazda geliştirilen Örgütsel Travmatik Olaylar Ölçeği kullanıldı. Ölçek, 36 olayın "Şirketinizde çalışanların bu olayla karşılaşma ihtimali var mı?” (travmatik olaylara maruz kalma olasılığı) ve "Bu olayın ortaya çıkması 
önlenebilir mi?" (önlenebilme düzeyi) sorularıyla iki kez değerlendirilmesini içermektedir (Altılı Likert ölçeği; $1=$ kesinlikle hayır"; " $6=$ kesinlikle evet"). Travmatik olaya maruz kalma olasılığının, algılanan önlenebilme düzeyine oranı, maddede tanımlanan her senaryo için algılanan risk düzeyi göstergesini oluşturmaktadır. Bu oran, 1/6 (algılanan riskin en düşük seviyesi) ile 6/1 (algılanan riskin en yüksek seviyesi) arasında değișebilir, böylece altı puan, belirli bir travmatik olay için mümkün olan en yüksek risk düzeyini yansitır. Her bir potansiyel travmatik olay için bu hesap yapıldı, algılanan risk seviyeleri kullanılarak diğer istatistiksel analizler gerçekleştirildi.

İç tutarlılık analizi yapılan (Cronbach $\alpha=.87$ ) ölçekte yer alan 36 travmatik olayın gruplanışını incelemek için, algılanan risk puanlarını Çok Boyutlu Ölçekleme Analizine (Multi Dimensional Scaling, MDS) tabi tuttuk (Işı1k, 2017b). SPSS yazılımının PROXSCAL, MDS modülü, travmatik olayların risk algısı düzeyleri arasındaki ilişkiye dayalı olarak hangi eksenler ve boyutlara göre gruplanabileceğini yorumlama imkânı vermektedir. Olası travmatik olayların birbirleriyle korelasyonlarını (Pearson correlation coefficients) içeren matris tablo üzerinde, aralıklı MDS ve Simplex konfigürasyon ile çalışılmıştır [stres yakınsaklık değeri=.0001 (stress convergence), minimum stress $=.0001$, maksimum tekrar $=100]$.

Örgütsel Dayanıklılık Ölçeği (Kantur ve İşeri-Say, 2015) kullanılan ikinci ölçektir (altılı Likert cevap formatı; 1=Kesinlikle katılımıyorum; $6=$ Kesinlikle katıliyorum) ve iç tutarlılık (cronbach alfa) değeri 0,92'dir. Anket, cinsiyet, yaş, yönetici rolü, kıdem, sektör, örgüt büyüklüğü, çalıştıkları kurum türü sorularını da içermektedir.

\section{Bulgular}

Otuz altı travmatik olaya dair maruz kalma olasılığı, önlenebilme düzeyi ve algilanan risk için betimleyici istatistikleri Tablo 3'de verilmektedir. Algılanan risk puanı en yüksek olay tepe yönetimde yer alan kişilerin ayrılması/ölümü $(M=3.41, S D=2.30)$ ve savaş koşulları $(M=2.10, S D=1.66)$ iken, en düşük risk puanı çocuk işçi çalıştırma $(M=0.40, S D=0.57)$ için verilmiştir.

Tablo 3. Travmatik olaylara maruz kalma, önlenebilme ve algılanan risk puanı betimleyici istatistikleri (Algılanan risk puanına göre sirali)

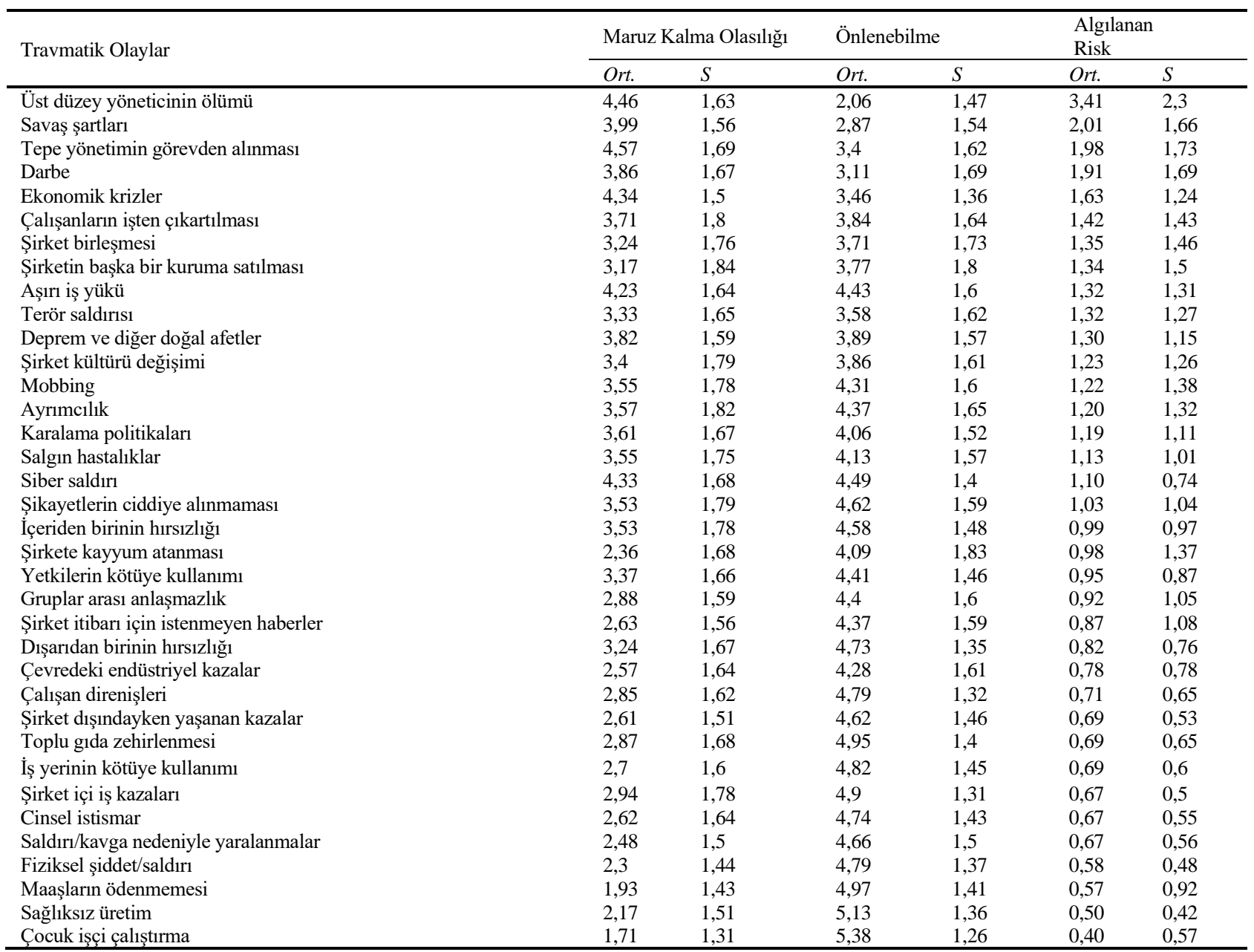


Çok Boyutlu Ölçekleme Analizi, travmatik olayların risk puanları açısından iki eksende ve yedi boyutta gruplanabileceğini göstermiştir (Uyum indeksi; Stres-I düzeyi=.295). Borg ve Groenen (2005), MDS analizinde ortaya çıkan yapının model olarak anlamlı olmasının önemi üzerinde durmaktadır. Travmatik olayların birbiriyle ilişkisi açısından gruplanışının teorik olarak anlam içerdiği ve Işık (2017a)'in araştırmasında sunduğu teorik taksonomiyle tutarlı bir yapı yarattığı görülmüştür.
MDS bulguları, travmatik olayların iki eksene yerleşebilen yedi boyutta gruplanabileceğini göstermektedir (Şekil 1). "Örgütsel düzeydeki etki" eksenine; (a) kontrol edilemeyendış kaynaklı olaylar; (b) finansal ve örgütsel değişim boyutları yerleşmiştir. "Bireysel düzeyde etki" ekseninde ise (a)kazalar, (b)şiddet, (c)kurum itibarını zedeleyen olaylar, (d)hırsızlık ve (e)psiko-sosyal risk içeren olaylar boyutları yer almaktadır.

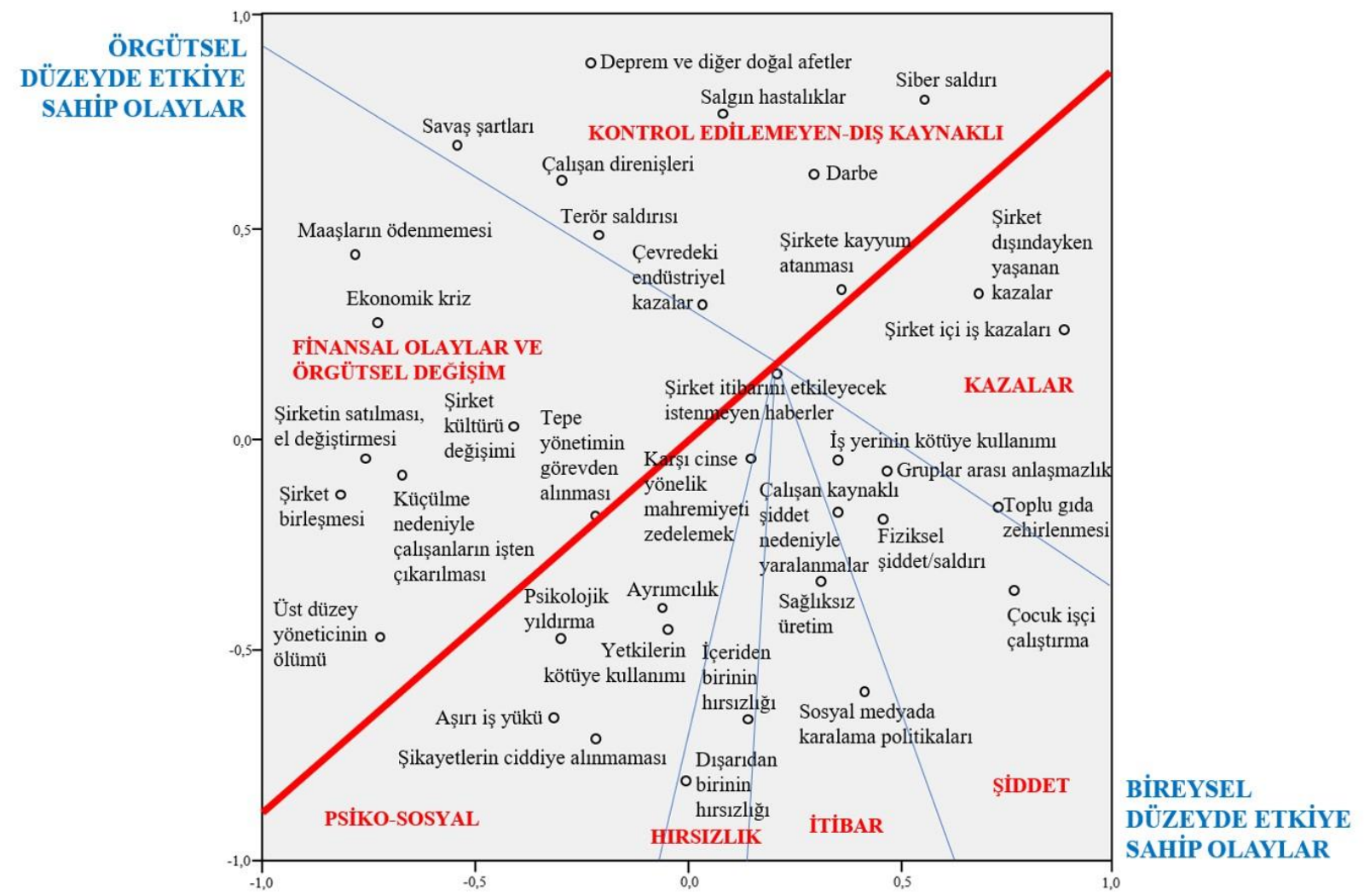

Şekil 1. Çok Boyutlu Ölçekleme Analizi neticesinde risk algısı puanlarına göre travmatik olayların eksenleri ve boyutları

Travmatik olayların iki ekseni ve yedi boyutunun hepsi dayanıklılık puanı ile istatistiksel olarak anlamlı ve negatif ilişki göstermektedir. Pearson korelasyon katsayılarına göre (Tablo 4), en yüksek korelasyon, dayanıklılık ile bireysel etkiye sahip olaylar $(r(145)=-.420, p=.000)$ ve itibar arasında $(r(145)=-.395, p=.000)$ gözlenmektedir. En düşük ilişki hırsızlık $(r(145)=-.208, p=.012)$ ve finansal/örgütsel değişimledir $(r(145)=-.192, p=.021)$. 
Tablo 4. Travmatik olayların eksenleri, boyutları ve örgütsel dayanıklılık arasındaki ilişki

\begin{tabular}{|c|c|c|c|c|c|c|c|c|c|c|c|}
\hline$N=145$ & Ort. & $S$ & 1 & 2 & 3 & 4 & 5 & 6 & 7 & 8 & 9 \\
\hline $\begin{array}{l}\text { 1.Kurum } \\
\text { itibarını } \\
\text { zedeleyen } \\
\text { olaylar }\end{array}$ & 0,86 & 0,69 & & & & & & & & & \\
\hline 2.Hırsızlık & 0,91 & 0,79 &, $29 *$ & & & & & & & & \\
\hline 3.Şiddet & 0,66 & 0,49 &, $52 *$ & & & & & & & & \\
\hline 4.Kazalar & 0,69 & 0,40 &, $34 *$ &, $30 *$ & , $46^{*}$ & & & & & & \\
\hline $\begin{array}{l}\text { 5.Psiko-sosyal } \\
\text { riskler }\end{array}$ & 1,07 & 0,83 &, $40 *$ &, $41^{*}$ & ,48* &, $23^{* * *}$ & & & & & \\
\hline $\begin{array}{l}\text { 6.Finansal- } \\
\text { örgütsel değişim }\end{array}$ & 1,62 & 0,90 &, $36^{*}$ & ,25* &, $22 * *$ &, $19 * * *$ &, $43^{*}$ & & & & \\
\hline $\begin{array}{l}\text { 7.Kontrol dışı- } \\
\text { dış kaynaklı }\end{array}$ & 1,26 & 0,64 &, $31 *$ & ,24* &, $44^{*}$ &, $34 *$ &, $29 *$ &, $41^{*}$ & & & \\
\hline $\begin{array}{l}\text { 8.Örgütsel } \\
\text { düzeyde etkili } \\
\text { olaylar }\end{array}$ & 1,44 & 0,65 &, $40 *$ & ,29* &, $37^{*}$ &, $30^{*}$ &, $44 *$ &, $89^{*}$ & ,78* & & \\
\hline $\begin{array}{l}\text { 9.Bireysel } \\
\text { düzeyde etkili } \\
\text { olaylar }\end{array}$ & 0,84 & 0,46 &, $72 *$ & ,71* & ,76* &, $56 *$ &, $77 *$ &, $44^{*}$ & ,43* &, $51^{*}$ & \\
\hline $\begin{array}{l}\text { 10.Örgütsel } \\
\text { dayanıklılık }\end{array}$ & 4,43 & 1,09 &,$- 40^{*}$ &,$- 21 * *$ &,$- 30^{*}$ &,$- 25^{*}$ &,$- 34 *$ &,$- 19 * * *$ &,$- 22 * *$ &,$- 24 *$ &,$- 42 *$ \\
\hline
\end{tabular}

Örgütsel dayanıklılık algısının travmatik olaylara dair algılanan riske etkisini incelemek için basit regresyon analizi uygulanmış, dayanıklılık bir yordayıcı olarak, tüm eksen ve boyutlarda istatistiksel anlamlı etki göstermiştir (Tablo 5).
En yüksek etki, bireysel düzeydeki olaylar ekseni üzerinde (Beta=-,420); kontrol edilemeyen-dış kaynaklı olaylar boyutunda (Beta=-,221); ve kurum itibarını zedeleyen olaylar boyutunda (Beta=-,395) görülmektedir.

Tablo 5. Örgütsel dayanıklılık algısının (yordayıcı), travmatik olaylar risk algısı üzerindeki etkisine dair regresyon analizi

\begin{tabular}{|c|c|c|c|c|c|c|c|}
\hline \multirow[b]{2}{*}{$\begin{array}{l}\text { Örgütsel } \\
\text { düzeyde etkili } \\
\text { olaylar }\end{array}$} & \multirow[b]{2}{*}{,052 } & \multicolumn{2}{|c|}{ Düzeltilmiş $R^{2}$} & ANOVA $^{b}$ & \multicolumn{2}{|c|}{ Katsayılar $^{a}$} & \multirow{2}{*}{$\begin{array}{c}\text { Etki Büyüklüğü } \\
p \\
\text { Küçük }\end{array}$} \\
\hline & & 8,86 & $\begin{array}{ll}\text { F } & \\
\end{array}$ & $\begin{array}{ll}p^{-, 242} \\
\end{array}$ & $\begin{array}{l}\text { Beta } \\
-2,97\end{array}$ & $\begin{array}{c}t \\
, 003\end{array}$ & \\
\hline $\begin{array}{l}\text { Bireysel düzeyde } \\
\text { etkili olaylar }\end{array}$ &, 171 & 30,6 & ,000 &,- 420 & $-5,53$ & ,000 & Orta \\
\hline $\begin{array}{l}\text { Finansal-örgütsel } \\
\text { değişim }\end{array}$ &, 030 & 5,46 &, 021 &,- 192 & $-2,33$ & ,021 & Küçük \\
\hline $\begin{array}{l}\text { Kontrol } \\
\text { edilemeyen-dış } \\
\text { kaynaklı }\end{array}$ &, 042 & 7,36 & ,007 &,- 221 & $-2,71$ & ,007 & Küçük \\
\hline Hirsızlık & ,037 & 6,49 & ,012 &,- 208 & $-2,54$ & ,012 & Küçük \\
\hline Kazalar & ,056 & 9,50 & ,002 &,- 250 & $-3,08$ & ,002 & Küçük \\
\hline Şiddet &, 082 & 13,9 & 000 &,- 298 & $-3,73$ &, 000 & $\begin{array}{l}\text { Küçük ila } \\
\text { orta }\end{array}$ \\
\hline $\begin{array}{l}\text { Psiko-sosyal } \\
\text { riskler }\end{array}$ &, 106 & 18,1 & 000 &,- 336 & $-4,26$ &, 000 & $\begin{array}{c}\text { Küçük ila } \\
\text { orta }\end{array}$ \\
\hline $\begin{array}{l}\text { Kurum itibarını } \\
\text { zedeleyen } \\
\text { olaylar }\end{array}$ &, 150 & 26,4 & 000 &,- 395 & $-5,14$ &, 000 & Orta \\
\hline
\end{tabular}


Bağımsız gruplar t-test analizi sonuçları (Tablo 6) yöneticilerin örgütsel düzeydeki travmatik olaylara dair risk algısının $(M=1,30, S D=0,57)$, yönetici olmayanlara göre $(M=1,55, \quad S D=0,69)$ daha düşük olduğunu göstermiştir
( $t=2,34, p=, 021$, Cohen's $d=0,38)$. Bireysel düzeyde etkisi olan olaylarda da istatistiksel olarak anlamlı fark gözlenmiştir $(t=2,79, \quad p=, 06$, Cohen's $d=0,47$, yöneticiler $M=0,72$, $S D=0,36$, yönetici olmayanlar $M=0,93, S D=0,51)$.

Tablo 6. Yöneticiler ve yönetici olmayanların travmatik olaylar için risk algıları

\begin{tabular}{|c|c|c|c|c|c|c|c|c|}
\hline $\begin{array}{l}\text { Travmatik olayların boyut ve } \\
\text { segmentleri }\end{array}$ & Yöneticilik Rolü & $N$ & Ort. & $S$ & $t$ & $p$ & $\begin{array}{l}\text { Cohen's } \\
d\end{array}$ & Etki Büyüklüğü \\
\hline \multirow{2}{*}{$\begin{array}{l}\text { Örgütsel düzeyde } \quad \text { etkili } \\
\text { olaylar }\end{array}$} & Yönetici & 68 & 1,30 & 0,57 & 2,34 &, 021 & 0,38 & Küçük ila orta \\
\hline & Yönetici değil & 77 & 1,55 & 0,69 & & & & \\
\hline \multirow{2}{*}{$\begin{array}{l}\text { Bireysel } \\
\text { olaylar }\end{array}$} & Yönetici & 68 & 0,72 & 0,36 & 2,85 &, 005 & 0,47 & Küçük ila orta \\
\hline & Yönetici değil & 77 & 0,93 & 0,51 & & & & \\
\hline \multirow{2}{*}{$\begin{array}{l}\text { Kontrol edilemeyen- } \\
\text { dış kaynaklı }\end{array}$} & Yönetici & 68 & 1,09 & 0,50 & 2,99 & ,003 & 0,49 & Orta \\
\hline & Yönetici değil & 77 & 1,39 & 0,71 & & & & \\
\hline \multirow[t]{2}{*}{ Finansal-örgütsel değişim } & Yönetici & 68 & 1,51 & 0,85 & 1,30 &, 194 & 0,21 & Küçük \\
\hline & Yönetici değil & 77 & 1,71 & 0,93 & & & & \\
\hline \multirow[t]{2}{*}{ Psiko-sosyal riskler } & Yönetici & 68 & 0,86 & 0,71 & 2,81 &, 006 & 0,46 & Küçük ila orta \\
\hline & Yönetici değil & 77 & 1,24 & 0,88 & & & & \\
\hline \multirow[t]{2}{*}{ Kazalar } & Yönetici & 68 & 0,69 & 0,41 & $-0,04$ & ,962 & 0,00 & Etki yok \\
\hline & Yönetici değil & 77 & 0,68 & 0,38 & & & & \\
\hline \multirow[t]{2}{*}{ Şiddet } & Yönetici & 68 & 0,54 & 0,33 & 2,76 &, 007 & 0,45 & Küçük ila orta \\
\hline & Yönetici değil & 77 & 0,75 & 0,58 & & & & \\
\hline \multirow[t]{2}{*}{ Hirsızlık } & Yönetici & 68 & 0,79 & 0,48 & 1,78 & ,078 & 0,29 & Küçük ila orta \\
\hline & Yönetici değil & 77 & 1,01 & 0,96 & & & & \\
\hline \multirow{2}{*}{$\begin{array}{l}\text { Kurum itibarını zedeleyen } \\
\text { olaylar }\end{array}$} & Yönetici & 68 & 0,73 & 0,52 & 2,03 &, 044 & 0,33 & Küçük ila \\
\hline & Yönetici değil & 77 & 0,96 & 0,79 & & & & orta \\
\hline
\end{tabular}

Finansal-örgütsel değişim, kazalar ve hırsızlık dışında diğer tüm boyutlar da iki grup arasında küçük ile ortalama büyüklükte etkiye sahip, istatistiksel olarak anlamlı farklar içermektedir.

Diğer taraftan yönetici olanlar ve olmayanların örgütsel dayanıklılık algıları arasında istatistiksel olarak anlamlı fark bulunmamaktadır $[t(143)=-, 749, \quad p=, 455$, yönetici olmayan ortalama $=4,37, S=1,088$, yönetici ortalama $=4,51, S=1,09$ ]

\section{Tartışma}

Örgütsel travmalar, psikoloji alanyazınında halen az çalışılan bir olgudur. Çalışma yaşamı, örgütsel süreçler, işyerinde geçirilen zaman yetişkinlerin psikolojik sağlığını ve iyilik halini şekillendiren en önemli sosyal bağlamlardandır. Örgütün iç süreçlerinden veya içinde bulunduğu dış koşullardan kaynaklanan olumsuz olaylar, tüm çalışanlar üzerinde kısa ya da uzun süreli, hafif ya da kuvvetli bir rahatsızlık hissi uyandırabilir, bireyler bunlarla başa çıkamayabilir. Çalışanların hangi olayları ne düzeyde risk olarak algıladığını anlamak, farklı olayların çalışma yaşamında travmatik etkilerini inceleyebilmek için ilk adımdır. $\mathrm{Bu}$ yaklaşım, örgütsel travma olgusunun teorik modellemesine imkan tanır; ölçüm araçlarının geliştirilmesi için bir çerçeve sunar. Bu amaçla tasarlanan araștırmamız da örgütsel travmatik olayların sistematik şekilde gruplanabileceği göstermektedir. Örgütsel travmatik olayların, Işık'ın (2017) daha önce kavramsal bir modelle sunduğu taksonomiyle tutarlı eksenlere ve boyutlara ayrıldığ gözlenmiştir. Travmatik olaylar örgütsel ya da bireysel etkilerine göre gruplanabilmektedir. Bireyin kontrol edebildiği veya kontrol edemediği, örgütsel süreçlerden kaynaklanan travmatik olaylar ve ekonomik, sosyal ve çevresel koşulların neden olduğu olaylar farklılaşmıştır.

Organizasyonlar, çalışanlarının sağlığını korumak, stres yaratan, bireysel ya da örgütsel ölçekte başa çıkma kapasitesini zorlayan olayları önlemek için proaktif yaklaşımların önemini kabul etmektedir. Beklenmedik herhangi dikkat dağıtıcı bir durumla karşılaştıklarında nasıl başa çıkacakları konusunda iyileşme planları yaparlar. $\mathrm{Bu}$ planlama davranışı örgütlerin dayanıklılığına katkıda bulunur; sonucunda, kuruluşlar kendilerini dayanıklı örgütlere dönüştürebilirler (Sahebjamnia, Tarabi ve Mansouri, 2018). Mevcut araştırmada, olası travmatik olayların tüm eksenleri ve boyutları dayanıklılık ile negatif ve anlamlı korelasyona sahiptir. Bu, çalışanların yüksek örgütsel dayanıklılık algısının, travmatik örgütsel olaylar için daha 
düşük risk algısıyla ilişkili olduğu anlamına gelir. Patriarca, Di Gravio, Costantino, Falegnami ve Bilotta (2017), dayanıklılığın dört temel unsurundan bahseder. Dayanıklı bir sistem problemlere cevap üretebilmeli, altta yatan nedenleri tanımlayabilmeli, gelecekteki problemlere yol açabilecek tehditleri tanımlamalı ve aynı zamanda deneyimlenen süreçlerden öğrenmelidir. Bir organizasyonun bu dört unsur arasında sağladığı denge, beklenmedik durumlar karşısında dayanıklı hale gelmesini sağlar. Dolayısıyla, potansiyel olarak travma yaratabilecek olaylar karşısında dayanıklılık geliştirebilecek yaklaşım ve önlemleri almak örgütlerde şarttır.

$\mathrm{Bu}$ çalıșmanın en çarpıcı sonuçlarından biri, yönetimsel rolleri olan ve olmayan kişilerin risk algılamasındaki farklılıktır. Hem bireysel hem de örgütsel düzeyde olas1 travma senaryolarında, yöneticiler organizasyonun karşılaşabileceği olayları yönetici olmayanlar kadar riskli algilamamaktadır. Dickson, Price, Maclaren ve Stein (2004), sağlık kuruluşu yöneticilerinin, şiddet ve stresli olayları hemşirelere göre daha az riskli yorumladığını göstermiştir. $\mathrm{Bu}$ bulgu, yöneticilerin, kurumların karşılaşabileceği tehlikelere karşı önlem almak, farklı alternatif çözüm yolları düşünmek ve kolektif problem çözmeyi teşvik etmek sorumluluğuna sahip kişiler olduğunu düşünürsek çok önemlidir (Hillmann, Duchek, Meyr ve Guenther, 2018). Olayların risklerini düşük değerlendirme eğilimi, yöneticileri tedbir almaktan alıkoyabilir. Öte yandan, ekiplerinin travma sonras1 mücadele sürecini önemsemeyebilir ve empati kurmakta zorlanabilirler. Mevcut bulgular, kuruluşların bu konuda aksiyon almaları gerektiğini göstermektedir.

\section{Öneriler}

Potansiyel olarak hangi olayların örgütler ölçeğinde travmatik olarak tanımlanacağı, şu ana kadar detaylı şekilde açıklandığı gibi, kurumların iç ve dış koşullarında yaşanan deneyimlerden etkilenmektedir. Dolayısıyla, bu alandaki araştırma bulgularının, çalışmanın gerçekleştirildiği zaman ve yerdeki güncel olaylardan etkilenmesini beklemeliyiz. $\mathrm{Bu}$ araştırma, 2017-2018 yılları arasında, ülke ve dünya genelindeki terör saldırılarının haberlerde sıklıkla yer aldığ ve savaşın çok uzak bir konu olmadığ 1 bir dönemde gerçekleștirildi. Dolayısıyla, savaș (2.sırada), darbe (4.sırada) ve terör (10.sırada) riskli olaylar olarak karşımıza çıtı. Ancak o dönemde bile, salgın ihtimali odak grup katılımcıları tarafından, ülkenin bulunduğu coğrafya nedeniyle sürekli gündeminde olan depremle aynı sıklıkta gündeme getirildi, algılanan risk puanı siralamasinda da 20 maddeyi geride bıraktı. Covid-19 pandemisine bağlı olarak içinde bulunduğumuz bugünlerde, bu makalede yer alan travma tanımına oturacak çok farklı deneyimler, çalışma hayatında, yerel ve global ölçekte yaşanıyor; bireylerin ve örgütlerin dayanıklılığını ispatlaması gereken bir bağlam deneyimleniyor. Ancak araştırmamızın da gösterdiği gibi aslında bu çalışmanın katılımcıları o tarihte dahi olası bir salgın durumunu kurumları için potansiyel travmatik olaylar arasında ifade etmişler. $\mathrm{Bu}$ bulgu, örgütlerin dayanıklılığını artırma çalışmalarında, çalışanların perspektifini değerlendirmenin ve dikkate almanın önemini vurgulamaktadır.

Watkins ve Bazerman'a (2003) göre, "öngörülebilir sürprizleri" teşhis etmede üç engel vardır. $\mathrm{Bu}$ engeller politik, psikolojik ve örgütseldir. Politik engeller, bir grubun sesinin yükselmesi, diğerlerinin duyulmaması gibi organizasyondaki güç dengesi ile ilgilidir. Psikolojik engeller, olayları olduğundan daha iyi veya daha kötü görme gibi bilişsel yargıları içerir. Örgütsel engeller, akıcı olmayan bilgilerden kaynaklanır ve potansiyel tehditleri anlamayı zorlaştırır. Bunlara başa çıkmak için gereken beceriler; risklerin ve tehditlerin tanınması, olası tehditler için ortamın denetlenmesi ve tehditlerin düzeylerine göre aksiyon önceliklerinin belirlenmesidir (Vivian, Cox, Hormann ve Kangas, 2017). Bu kapsamda, Örgütsel Travmatik Olaylar Ölçeğinin, kuruluşların güvenli ve riskli durumları tespit etmesi ve risk algılanan durumlar için uygun planlar geliştirmesi için önemli bir araç olduğunu söyleyebiliriz. Çalışanların hangi olay veya davranışları riskli olarak algıladıklarını öğrenmek, örgütün zayıf noktalarını tanımak ve yöneticilere hangi alanlara odaklanacakları konusunda rehberlik etmek için sistematik bir çerçeve sunmaktadır.

Sonuç olarak araştırmamız, örgütsel travmaya dikkat çekerken, hazırlıklı olmayı destekleme ve farkındalığ artırma açısından bir rol üstlenmektedir. Bu yanıyla, diğer araştırmacıları ve örgütleri, insanların çalışma ortamlarında yaşayabilecekleri potansiyel travmatik olayların ampirik olarak araştırılmasına yönlendirebilecek bir kapsamı ve metodolojisi olduğunu söyleyebiliriz.

\section{Kaynaklar}

Annarelli, A. ve Nonino, F. (2016). Strategic and operational management of organizational resilience: current state of research and future directions. Omega, 62, 1-18.

Borg, I., ve Groenen, P. J. F. (2005). Modern multidimensional scaling: Theory and

applications (2nd ed.). New York, NY US: Springer Science + Business Media.

Buckley, T. ve Dunn, A. (2012). Healing the traumatized organization: an exploration of post-trauma recovery and growth in the workplace setting using the metaphor of nervous system as a template to highlight collective learning. In R. Hughes, A. Kinder ve C.L. Cooper (Eds.), International handbook of workplace trauma support (pp.350-367). UK: John Wiley ve Sons.
Burke, R.J. (2012). The trauma impact on organizations: causes, consequences, and remedies. In R. Hughes, A. Kinder ve C.L. Cooper (Eds.), International handbook of workplace trauma support (pp.71-85). UK: John Wiley ve Sons.

Cohen, J. (1998). Statistical power analysis for the behavioral sciences. Hillsdale, NJ: Erlbaum.

De Galizia, A., Simon, C., Weber, P., Iung, B., Ducal, C. \& Serdet, E. (2016). Markers and patterns of organizational resilience for risk analysis. IFAC-PapersOnLine, 49-19, 432-437.

De Klerk, S. (2007). Healing emotional trauma in organizations: an o.d. framework and case study. Organizational Development Journal, $25(1), 49-55$ 
Denenberg, R.V., ve Denenberg, T.S. (2010). Workplace violence: The American experience. In R. J. Burke ve C. L. Cooper (Eds.) Risky business: Psychological, physical and financial costs of highrisk behavior in organizations (pp. 375-402). Surrey: Gower.

Dickson, G.C.A., Price, L., Maclaren, W.M. ve Stein, W.M. (2004) Perception of risk: a study of A\&E nurses and NHS managers. Journal of Health Organization and Management, 18(5), 308-320.

Gabriel, Y. (2012). Organizations in a state of darkness: Towards a theory of organizational Miasma. Organization Studies, 33(9), 11371152

Hillmann, J., Duchek, S., Meyr, J. \& Guenther, E. (2018). Educating future managers for developing resilient organizations: the role of scenario planning. Journal of Management Education, 1-35, DOI: $10.1177 / 1052562918766350$.

Holling, C.S. (1973). Resilience and stability of ecological systems. Annual Review of Ecology and Systematics, 4, 1-23.

Hopper, E. (2010). Trauma and organizations. London: Karnac Books.

Hormann, S. ve Vivian, P. (2005). Toward an understanding of traumatized organizations and how to intervene in them. Traumatology, 11(3), 159-169.

Hormann, S. D. L. (2007). Organizational trauma: A phenomenological study of leaders in traumatized organizations. (Doctoral dissertation). Antioch University, Ohio.

Ișık, İ. (2014). Yokluk hipotezi anlamlılık testi ve etki büyüklüğü tartışmalarının psikoloji araştırmalarına yansımaları, Eleştirel Psikoloji Bülteni, 5, 55-80.

Işık, İ. (2017a). Organizations and exposure to trauma at a collective level: the taxonomy of potentially traumatic events. In S. Hasa ve R.B. Thornton (Eds), Impact of organizational trauma on workplace behavior and performance (pp. 18-57). USA: IGI Global.

Işık, İ. (2017b). Psikoloji Analındaki Uzmanlık Yönelimleri. In T.Turgut ve M. Cinko (Eds.) Değerler ve Kariyer Motivasyonu Değerli İnsana "Değer"li Çalışmalar. İstanbul: Beta Basım Yayım Dağıtım A.S.

Kantur, D. ve Iseri-Say, A. (2015). Measuring organizational resilience: A scale development. Journal of Business, Economics and Finance, 4(3), 456-472.

King, D., Newman, A. ve Luthans, F. (2016). Not if, but when we need resilience in the workplace. Journal of Organizational Behavior, 37, 782-786.
Limnios, E.A.M., Mazzarol, T., Ghadovani, A. \& Schilizzi, S.G.M. (2014). The resilience architecture framework: four organizational archetypes. European Management Journal, 32, 104-116.

Mandojana, N. \& Bansal, P. (2016). The long-term benefits of organizational resilience through sustainable business practices. Strategic Management Journal, 37, 1615-1631.

Noer, D. (1993). Healing the wounds: Overcoming the trauma of layoffs and revitalizing downsized organizations. San Francisco: Jossey-Bass.

Özbudak, E.C. (2018). Are you prepared? Measuring the level of perceived risk for organizational trauma and its relationship with organizational resilience Yayımlanmamıs yüksek lisans tezi, İstanbul Bilgi Üniveristesi. İstanbul, Türkiye.

Patriarca, R., Di Gravio, G., Costantino, F., Falegnami, A., ve Bilotta, F. (2017). An analytic framework to assess organizational resilience. Safety and Health at Work, 1-12.

Pena, P.A., Broucke, S., Sylin, M., Leysen, J., ve Soir, E. (2017). Definitions, Typologies, and Processes Involved in Organizational Trauma: A Literature Review. In S. Hasa ve R.B. Thornton (Eds), Impact of organizational trauma on workplace behavior and performance (pp. 1-17). USA: IGI Global.

Powley, E.H. (2012). The process and mechanisms of organizational healing. The Journal of Applied Behavioral Science, 49(1), 42-68.

Sahebjamnia, N., Tarabi, S.A. ve Mansouri, S.A. (2018). Building organizational resilience in the face of multiple disruptions. International Journal of Production Economics, 197, 63-83.

Somers, S. (2009). Measuring resilience potential: an adaptive strategy for organizational crisis planning. Journal of Contingencies and Crisis Management, 17(1), 12-23.

Steinkamp, M. (2014). Behind the masks of silence: How leaders can overcome organizational trauma (Unpublished master's thesis). INSEAD, Fontainebleau.

Stuart, R. (1996). The trauma of organizational change. Journal of European Industrial Training, 20(2), 11-16.

Venugopal, V. (2016). Understanding organizational trauma: a background review of types and causes. Journal of Business and Management, 18(10), 65-69.

Vivian, P., Cox, K., Hormann, S., ve Kangas, S. (2017). Healing traumatized organizations: reflections from practitioners. $O D$ Practitioner, 49(4), 45-51.

Watkins, M. D., \& Bazerman, M. H. (2003, March). Predictable surprises: The disasters you should have seen coming. Harvard Business Review, 72-80. 